\title{
NOTES A L'ASSAIG DE JOSE LUIS ARANGUREN SOBRE LA JOVENTUT EUROPEA
}

\author{
Oriol Homs \\ (Sociòleg)
}

La relectura de l'assaig de José Luis Aranguren sobre la joventut eutopea indueix a reflexions plenes d'actualitat i desmitifica una expressió molt sentida en medis «experts» sobre el jovent: «En matèria de joves no hi ha res segur, tot canvia a velocitats esfereïdores; el que ahir era cert, avui ja no ho és.»

Aranguren ja detectava fa vint-i-tres anys que la joventut dels anys cinquanta es «desentenia» dels «models» proposats per les generacions anteriors. I ja observava una «anormal prolongació de l'etapa juvenil». Encara no s'havia «inventat» «l'adolescència forçosa» ni es parlava de l'atur juvenil, sinó més aviat al contrari, es denunciava la sobreexplotació del treball infantil.

Els joves ja eten «escèptics, realistes, inclinats a les coses concretes, positives, privades, utilitàries, funcionals, tècniques...» $\mathrm{i}$ encara no havia succeit el plorat Maig del 68 a Europa, ni la frustrant «transició política» a l'Estat espanyol. Tot plegat fa pensar que a part d'efectes conjunturals $i$ generacionals es constaten unes permanències que cal emmarcar en cootdenades socials $i$ temporals més àmplies.

I, en canvi, qui s'atreviria, avui, a afirmar que la joventut dels anys cinquanta i la dels anys vuitanta és la mateixa? Què ha succeït? Són aspectes formals els que han canviat, o hom es troba davant de dues joventuts que han viscut esdeveniments que les han marcat generacionalment 
en un mateix sentit, per utilitzar els mateixos termes de l'article comentat: «La guerra civil i la crisi econòmica». $O$ bé el que ha variat ha estat «la mirada adulta sobre la gent jove».

En el Post Scriptum - la part més lúcida de l'article--, Aranguren sembla apuntar una resposta a aquest conjunt de contradiccions: la seva anàlisi, no és també un retrat dels adults? Aquest dubte s'ha oblidat massa sovint. Molts dels estudis que shan realitzat sobre la joventut són pràcticament constatacions de les característiques generals de la societat a la qual pertany la joventut estudiada.

Com ja ha assenyalat repetides vegades Estruch, no està clar que la joventut sigui un objecte pertinent d'anàlisi científica. $\mathrm{O}$ com a mínim cal definir-lo. En quins aspectes els fenònens juvenils presenten una autonomia pròpia que permet estudiar-los diferenciadament de la resta de la societat? Aquest aspecte epistemològic de la joventut com a objecte d'estudi no és innocu i demana una anàlisi per si mateix.

Una cosa és confondre els fenòmens juvenils amb els fenòmens socials més globals i una altra és que freqüentment les anàlisis sobre els joves són interpretacions adultes sobre el que són $i$ el que fan els joves. Hom creu veture joventuts diferents on $\tan$ sols hil ha diferents interpretacions o diferents aduits que interpreten.

Un exemple el tenim a l'article que comentem: la part menys interessant analíticament, però molt vàlida des d'una perspectiva de sociologia històrica, és la interpretació que l'Atanguren fa de la joventut dels cinquanta $i$ que compartia amb tot un sector social format, a grans trets, per un catolicisme progressista, per una certa intellectualitat, per sectors liberals i democràtics, en el context de la dictadura franquista i en el marc dels debats d'aleshores entre tercermundisme i desenvolupament, dictadura i detnocràcia, cultura $i$ analfabetisme, progrés i tradició. Des d'aquests sectors, el concepte joventut formava part d'un conjunt més ampli, junt amb conceptes com progrés $i$ futur, contraposats a adult, tradició i passat.

En canvi, actualment el marc conceptual ha variat completament. Els joves ja no són el futur, sinó el present sense el pes de la tradició. El futur ja no és patrimoni dels joves, sinó també dels adults que s'han futuritzat. La joventut en aquesta situació queda com a subproducte a integrar o tecuperar.

La joventut dels cinquanta era en bona part flla de la tradició, i la dels vuitanta ho és de la modemitat. La diferent maternitat, més que la fliació, explica la diferència entre el que es deia, es pensava o s'escrivia abans i el que es diu, es pensa o s'escriu ata sobre els joves.

Per aquest camí difícilment es pot fer una aproximació al coneixement objectiu de la joventut. Hom pot constatar la decadència del discurs pro- 
gressista dels adults sobre els joves o detenir-se a estudiar més exhaustivament aquestes relacions. Però això són figues d'un altre paner.

En canvi, hom observa la progressiva constitució d'un món específic dels joves, amb unes relacions socials i uns elements culturals propis. Possiblement, a l'Estat espanyol, els anys cinquanta marquen els límits d'una etapa d'aquest procés. Els canvis que s'han produit a partir d'aquesta data: generalització de l'escolatització, canvis tecnològics, retard en la incorporació dels joves al mercat de treball, augment del nivell cultural, penetració del consumisme com a pauta general de conducta, transformació de l'organització familiar i comunitària, urbanització i tancament dels espais urbans, desenvolupament dels mitjans audiovisuals de comunicació... han provocat un salt qualitatiu en el procés - que arranca des del naixement de la societat industrial-- de definició de la posició i del paper dels joves dins la societat.

L'estudi d'aquest procés i d'aquests fenòmens socials constitueix una via per avançar en el coneixement dels joves d'avui. Tenint en compte, però, que el concepte de jove és inestable, ja que va intimament unit al de generació, i per tant cada generació jove viurà les seves posicions socials en contrast amb uns fets $i$ en relació a altres aglomerats socials de manera distinta.

Massa sovint el discurs sobre els comportaments dels joves posa l'èmfasi en el fet biològic d'ésser jove. Normalment es pensa, $i$ alguns estudio. sos repeteixen de vegades, que els joves es comporten d'una determinada manera pel fet de ser joves biològicament, per tenir una edat determinada. Ni la psicologia ha afirmat que existeixi una personalitat jove ni s'ha demostrat que característiques biològiques determinin el comportament humà. Per tant, caldrà cercat en el camp social l'explicació de les regularitats del comportament dels joves. Això sense oblidar que el fet de coincidir processos evolutius semblants de diferents personalitats pot explicar certs tipus de comportament juvenil.

En aquest sentit cal un esforç de precisió en les categories descriptives - analítiques que es proposen com a marc teòtic per a l'estudi de la joventut, perquè siguin útils i clariffcadores.

Per fi, un altre dels trets a comentar de l'article d'Aranguren és l'enfocament unitari i global de la joventut. Malgrat que el mateix autor ho matisa, possiblement sigui una limitació deguda al moment en què Aranguren tealitza l'anàlisí. Si entorn dels anys cinquanta podem definir una nova etapa en l'evolució de la joventut com a categoria social, qualsevol observador d'aquella època estava més interessat per la comprensió del fenomen en si, cercant l'explicació en la seva globalitat. En canvi, una vegada desenvolupada aquesta etapa apareixen amb més intensitat les con- 
tradiccions internes i la diferenciació més meticulosa dels seus components. Des d'aquest punt de vista es justificaria que avui hom es pregunti per «les joventuts» i no per una sola joventut.

Hom ha cercat aquestes diferències en la divisió tradicional de la som cietat en classes socials, però el resultat no acaba de correspondre's amb la realitat. Crec que els diferents tipus de joventut tenen més a veure amb els diferents ritmes $\mathrm{i}$ articulacions amb els quals s'han produit els canvis socials que s'han esmentat abans, com a factors coadjuvants en la constitució del món juvenil. És a dir, que la diferent articulació deis joves en els processos de canvi descrits defineix joventuts diferents.

És evident que aquests canvis socials estan interrelacionats amb les classes socials, però les seves repercussions sobre la joventut no es poden reduir a la influència de les classes socials.

En síntesi, un article que cal no oblidar. 